BIOFARM

Jurnal Ilmiah Pertanian

ISSN Print: 0216-5430; ISSN Online: 2301-6442

Vol. 16, No. 1, April 2020

\title{
Deteksi Virus Mosaik pada Tanaman Pepaya (Carica papaya L.) Berdasarkan Kisaran Inang
}

\author{
Mosaic Virus Detection Based on Plant Papaya (Carica papaya L.) Host \\ Range
}

\author{
Nining Triani Thamrin \\ Program Studi Agroteknologi, Fakultas Sains dan Teknologi, Universitas Muhammadiyah \\ Sidenreng Rappang \\ *Korespondensi Penulis: niningtriani1606@gmail.com
}

\begin{abstract}
ABSTRAK
Pertanaman pepaya di Kabupaten Toraja Utara, Kabupaten Gowa Sulawesi Selatan dan Kabupaten Mamasa Sulawesi Barat menunjukkan gejala mosaik yang berat pada bagian daun. Penelitian ini bertujuan untuk mengetahui kisaran inang virus penyebab penyakit mosaik pada tanaman papaya berdasarkan gejala penyakit. Dalam penelitian ini menggunakan sampel daun tanaman pepaya yang bergejala mosaik dan variasi gejala lainnya dikumpulan dari beberapa tempat pertanaman pepaya di Kabupaten di Sulawesi Selatan dan Sulawesi Barat. Propagasi virus pada tanaman dilakukan dengan melakukan metode sap-inoculation. Keberadaan penyakit mosaik dan tanaman sakit dideteksi dengan kajian biologi yakni pengujian pada tanaman inang indikator. Hasil pengujian respon tanaman indikator terhadap 25 isolat virus mosaik secara mekanik memperlihatkan 19 isolat virus yang dapat menginfeksi kelima tanaman indikator dengan persentase penularan dan lama periode inkubasi virus berbeda-beda.
\end{abstract}

Kata Kunci : pepaya, virus mosaik, kisaran inang

\section{ABSTRACT}

Papaya crop in North Toraja Regency, Gowa in South Sulawesi and West Sulawesi Mamasa showed severe mosaic symptoms on the leaves. Mosaic virus detection based host range is performed to determine the host range of viruses that cause disease in plants of papaya mosaic. This study used a sample of the papaya plant leaf mosaic symptoms and other symptoms dikumpulan variation of the few places in the papaya crop districts in South Sulawesi and West Sulawesi. The aims to detect the presence of disease causing mosaic that infects papaya plants with host range. The existence of mosaic disease and diseased plants detected by the study of the biological indicator testing on host plants. The test results of the 25 indicators of plant responses mosaic virus mechanically isolates showed 19 isolates a virus that can infect the plant fifth indicator on the percentage of transmission and the long incubation period of the virus is different.

Keywords: papaya, mosaic virus, host range

\section{PENDAHULUAN}

Pepaya (Carica papaya L.) merupakan salah satu jenis tanaman buah-buahan yang berasal dari Meksiko bagian selatan dan Kostarika di Amerika Tengah dan saat ini telah menyebar luas pertanamannya di seluruh dunia. Tanaman papaya berupa herba yang dikelompokkan ke dalam famili Caricaceae (Garret, 2011). Tanaman ini dapat tumbuh di dataran rendah maupun dataran tinggi, baik di wilayah tropis ataupun subtropis, serta dapat ditanam di wilayah yang beriklim basah dan kering (Soedarya, 2009). Komoditas buahbuahan ini sangat disukai oleh seluruh lapisan masyarakat karena cita rasanya yang enak, kaya dengan vitamin $A, B$ dan $C$ yang dibutuhkan oleh tubuh manusia. Di Eropa dan di negara maju lainnya, pepaya dimakan sebagai buah segar atau sari buahnya diminum pada pagi hari sebelum sarapan dengan maksud memperlancar pencernaan. Bagian dari buah pepaya yang dapat dimakan adalah sebesar $75 \%$ dari seluruh buah pepaya. 
Infeksi virus dalam kelompok potyvirus pada tanaman pepaya dan tanaman Cucurbitaceae lainnya, seperti mentimun, melon dan semangka menyebabkan terbentuknya gejala belang yang disebut karakter mosaik yang muncul diakibatkan terbentuknya warna yang bercampur antara warna hijau normal dan hijau muda atau kekuningan pada tanaman (Hidayat, 2012). Gejala lain yang seringkali juga muncul akibat infeksi virus pada pepaya adalah bercak cincin, pemanjangan, penyempitan dan malformasi pada daun (Jamsari, 2007). Tanaman yang lebih muda saat terinfeksi menunjukkan gejala yang lebih berat. Tanaman dapat terinfeksi oleh dua atau lebih virus dan menyebabkan gejala yang lebih berat daripada tanaman yang hanya terinfeksi oleh satu virus, (Davis and Mazumi, 2007; Brunt, et al., 2011; Mazumi, et al., 2007). Infeksi virus penyebab mosaik utama pada pepaya sulit untuk dibedakan hanya berdasarkan gejala pada permukaan tanaman (Nameth, 2005).

Berdasarkan uraian di atas menunjukkan bahwa penyakit mosaik yang disebabkan oleh potyvirus pada pepaya merupakan penyakit yang berpotensi menimbulkan masalah besar pada tanaman pepaya atau cucurbita lainnya dan dapat menginfeksi tanaman dalam kelompok suku lainnya, baik infeksi langsung maupun sebagai sumber inokulum, sehingga diperlukan upaya pengembangan metode pengendalian yang efektif. (Jensen et al., 2010) mengatakan bahwa pengendalian virus tanaman akan efektif apabila informasi tentang penyebab diketahui secara akurat Brunt (dalam Noveriza, et al., 2012) menambahkan bahwa identifikasi spesies virus yang terlibat dalam penyakit tumbuhan diperlukan untuk memantau kejadian penyakit, untuk mengidentifikasi sumber virus dan untuk merekomendasikan tindakan pengendalian yang tepat dan hingga saat ini laporan mengenai Potyvirus penyebab mosaik pada pepaya (C. papaya L.) atau cucurbita lainnya di Sulawesi Selatan masih terbatas sehingga penelitian ini perlu dilakukan. Penelitian ini bertujuan untuk mengetahui kisaran inang virus penyebab penyakit mosaik pada tanaman papaya berdasarkan gejala penyakit pada beberapa kisaran inang.

\section{BAHAN DAN METODE \\ Penyiapan Sumber Inokulum dan Propagasinya}

Sampel tanaman bergejala mosaik yang menyerupai infeksi potyvirus diperoleh dari beberapa pertanaman pepaya di Kabupaten Gowa, Kabupaten Toraja Utara, Sulawesi Selatan dan Kabupaten Mamasa, Sulawesi Barat. Bagian daun dari tanaman yang dikoleksi dari lapangan lebih lanjut digunakan sebagai sumber inokulum untuk propagasi virus pada tanaman sehat dan pengujian lainnya.

Propagasi virus pada tanaman dilakukan dengan melakukan metode sapinoculation, yakni daun tanaman pepaya yang bergejala digerus menggunakan mortar dan pistil steril. Larutan buffer fosfat sebagai larutan inokulasi $0,01 \mathrm{M}(\mathrm{pH} \mathrm{7.0)}$ ditambahkan ke dalam mortar sebanyak $1 \mathrm{ml}$. Selanjutnya, sebanyak 10 tanaman yang berumur 10 hari dan telah dipersiapkan sebelumnya ditaburi dengan karborundum 600 mesh pada bagian kotiledon untuk menimbulkan pelukaan, lalu cairan perasan tanaman yang telah digerus dioleskan pada permukaan kotiledon. Segera setelah pengolesan dilakukan pembilasan sisa-sisa cairan perasaan yang masih melekat pada permukaan daun tanaman uji menggunakan air mengalir.

\section{Respon Tanaman Indikator}

Tanaman uji yang digunakan sebagai tanaman indikator untuk kisaran inang, yakni Chenopodium amaranticolor, Nicotiana benthamiana, labu kuning (Cucurbita moschata), mentimun (Cucumis sativus) dan pepaya (Carica papaya L.). Benih tanaman uji sehat ditanam di dalam polybag yang berisi tanah dan pupuk kandang (perbandingan 2 : 1). Benih-benih tersebut dipelihara setiap hari. Tanaman uji yang telah membentuk daun sempurna akan diinokulasi dengan cairan perasan daun pepaya yang bergejala mosaik. Masing-masing jenis tanaman uji terdiri dari 10 tanaman. 


\section{HASIL DAN PEMBAHASAN}

\section{Sebaran Virus}

Berdasarkan hasil pengamatan dari 3 lokasi pertanaman papaya yang berbeda di Kabupaten Toraja Utara, Kabupaten Gowa (Provinsi Sulawesi Selatan) dan Kabupaten Mamasa (Provinsi Sulawesi Barat) ditemukan sampel tanaman menunjukkan variasi gejala mosaic yang mengindikasikan adanya variasi infeksi potyvirus pada tanaman papaya (gambar 1).

\section{Gejala Infeksi Potyvirus di Lapangan}

Gejala yang diamati pada tiga lokasi pangambilan sampel tanaman berupa mosaik dan belang yang ditunjukkan dengan gejala helaian daun belang hijau, helai daun belang berwarna kuning cerah yang berkembang menjadi warna kuning yang sangat jelas disertai dengan perubahan bentuk daun menjadi lengkung dan mengeriting/ malformasi (gambar 2).

Tabel 1. Rata-rata persentase penularan, bentuk gejala dan masa inkubasi 25 isolat virus mosaik pada 5 tanaman indicator.

\begin{tabular}{|c|c|c|c|c|c|c|c|}
\hline \multirow{2}{*}{ Isolat } & \multicolumn{5}{|c|}{ Persentase Penularan (\%) } & \multirow{2}{*}{$\begin{array}{l}\text { Bentuk } \\
\text { Gejala }\end{array}$} & \multirow{2}{*}{$\begin{array}{c}\text { Masa } \\
\text { Inkubasi (hari) }\end{array}$} \\
\hline & N.b & C.a & C.p & C.m & C.s & & \\
\hline TO 1-2 & 0 & 0 & 0 & 0 & 0 & - & - \\
\hline TO 1-3 & 20 & 0 & 40 & 40 & 20 & $\mathrm{M}, \mathrm{Ne}$ & $8-15$ \\
\hline TO 1-4 & 0 & 0 & 20 & 20 & 20 & $M$ & $10-18$ \\
\hline TO 1-5 & 0 & 0 & 0 & 0 & 0 & - & - \\
\hline TO 2-1 & 0 & 0 & 60 & 20 & 20 & M & $7-16$ \\
\hline TO 2-4 & 0 & 20 & 40 & 20 & 40 & $M$ & $10-18$ \\
\hline TO 2-5 & 20 & 0 & 100 & 0 & 0 & $\mathrm{M}, \mathrm{Ne}$ & $10-19$ \\
\hline MM 1-1 & 0 & 0 & 20 & 20 & 40 & $\mathrm{M}, \mathrm{Ne}$ & $6-13$ \\
\hline MM 1-2 & 0 & 20 & 0 & 0 & 20 & M & $8-16$ \\
\hline MM 1-5 & 20 & 0 & 40 & 40 & 0 & $\mathrm{M}, \mathrm{Vb}$ & $8-12$ \\
\hline MM 2-2 & 0 & 0 & 0 & 0 & 0 & - & - \\
\hline MM 2-3 & 0 & 0 & 40 & 20 & 20 & M & $9-15$ \\
\hline MM 2-4 & 0 & 0 & 0 & 0 & 0 & - & - \\
\hline MM 3-1 & 20 & 0 & 20 & 20 & 0 & $\mathrm{M}$ & $11-19$ \\
\hline MM 3-3 & 0 & 0 & 20 & 40 & 20 & $\mathrm{M}, \mathrm{Ne}$ & $12-19$ \\
\hline MM 3-4 & 0 & 20 & 20 & 60 & 20 & $\mathrm{M}, \mathrm{Ne}$ & $10-17$ \\
\hline MM 4-1 & 20 & 20 & 0 & 20 & 0 & M & $6-10$ \\
\hline MM 4-2 & 0 & 20 & 0 & 20 & 20 & $\mathrm{M}, \mathrm{Ne}$ & $9-15$ \\
\hline MM 5-3 & 0 & 40 & 20 & 40 & 0 & $M$ & $7-13$ \\
\hline MM 5-4 & 0 & 0 & 0 & 0 & 0 & - & - \\
\hline MM 5-5 & 0 & 20 & 20 & 40 & 20 & $\mathrm{M}, \mathrm{Ne}$ & 8-16 \\
\hline GW 1-1 & 20 & 20 & 20 & 40 & 0 & M & $9-15$ \\
\hline GW 1-3 & 0 & 0 & 40 & 20 & 20 & $\mathrm{M}, \mathrm{Vb}$ & $10-18$ \\
\hline GW 1-4 & 0 & 0 & 20 & 0 & 0 & - & - \\
\hline GW 1-5 & 0 & 40 & 20 & 40 & 0 & $\mathrm{M}, \mathrm{Ne}$ & $7-14$ \\
\hline
\end{tabular}

Ket. : $\mathrm{Nb}=$ Nicotiana benthamiana; $\mathrm{Ca}=$ Chenopodium amaranticolor $; \mathrm{Cp}=$ Carica papaya; $\mathrm{Cm}=$ Cucurbita moschata $; \mathrm{Cs}$ = Cucumis sativus; $\mathrm{M}=$ Mosaik; $\mathrm{Ne}=$ Nekrotik, $\mathrm{Vb}=\mathrm{Vein}$ banding; $\mathrm{TO}=$ Toraja; $\mathrm{MM}=\mathrm{Mamasa} ; \mathrm{GW}=\mathrm{Gowa}$ 


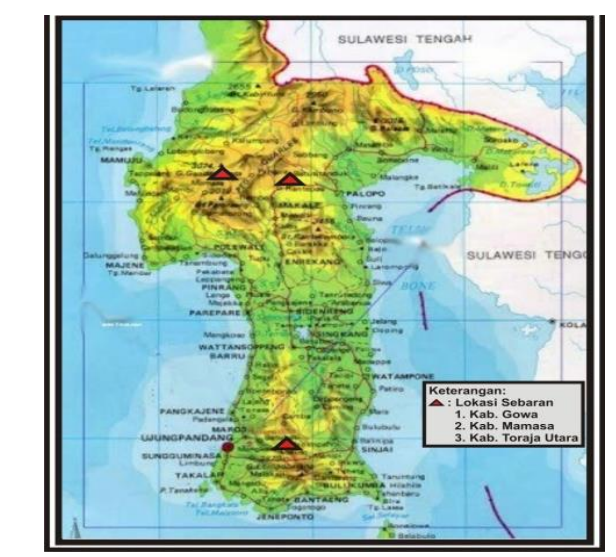

Gambar 1. Sebaran Potyvirus pada 3 Lokasi Pengambilan Sampel di Provinsi Sulawesi Selatan dan Sulawesi Barat

Gejala mosaik yang ditemukan dari berbagai daerah yang diduga oleh infeksi virus tidak bisa dilakukan berdasarkan deskripsi gejala saja, oleh sebab itu perlunya dilakukan identifikasi virus. Untuk mendapatkan gejala yang khas dari setiap infeksi virus, maka perlu dilakukan inokulasi virus pada tanaman sehat dan diamati karakteristik gejalanya. Data rata-rata persentase penularan, bentuk gejala dan masa inkubasi 25 isolat virus mosaik pada 5 tanaman indikator disajikan pada Tabel 1.

Hasil pengujian respon tanaman indikator terhadap 25 isolat virus mosaik secara mekanik memperlihatkan 19 isolat virus yang dapat menginfeksi kelima tanaman indikator dengan persentase penularan dan lama periode inkubasi virus berbeda-beda, sedangkan 6 isolat lainnya tidak dapat menginfeksi tanaman indikator. Rata - rata prsentase penularan virus mosaik pada tanaman indikator bervariasi antara $20 \%$ $100 \%$. Isolat TO 2-5 menunjukkan persentase penularan virus tertinggi yang mencapai 100 $\%$.

Munculnya gejala awal pada permukaan tanaman indikator beragam bergantung pada masa inkubasi yang berkisar

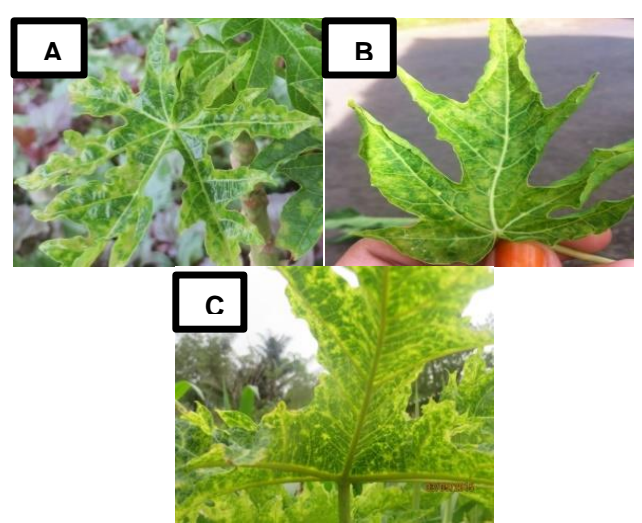

Gambar 2. Variasi gejala infeksi virus mosaic pada pepaya di beberapa lokasi, A. mosaik pada daun di Kab.Toraja Utara, B. mosaik pada daun di Kab.Gowa, C. mosaik pada daun di Kab.Mamasa

antara 6 sampai 19 hari. Hal ini dapat disebabkan karena adanya perbedaan virulensi virus. Hal ini sesuai dengan pendapat Gonsalves et al (2010), bahwa terjadinya variasi gejala pada beberapa tanaman indikator dapat terjadi karena perbedaan sifat virulensi suatu virus, yang umumnya terjadi sebagai mutasi pada gen virulensi virus. Mutasi gen dapat mengakibatkan terjadinya perubahan fungsi gen, sehingga dapat menyebabkan perubahan gejala yang muncul atau virulensi virus.

Bentuk gejala yang muncul pada tanaman pepaya dan tumbuhan lainnya sebagai tanaman indikator yang terinfeksi virus mosaik pada daunnya memperlihatkan gejala belang-belang kuning, bercak-bercak hijau gelap, dan kadang pola bercaknya menyatu ke tulang daun didekatnya, diikuti oleh menggulungnya, epinasti dan nekrosis, klorosis dan lokal nekrotik (Singh et al., 2009). Berdasarkan masa inkubasi, kejadian penyakit dan variasi gejala yang ditimbulkan pada penelitian ini, tanaman-tanaman dari famili Labiateae dan Solanaceae sangat potensial sebagai inang alternatif virus mosaik pepaya. Pada pengamatan di lokasi 
pengambilan sampel tanaman terlihat bahwa tanaman yang terinfeksi terletak berdekatan antara tanaman sehat sehingga ada kemungkinan terjadinya penularan virus ke tanaman sehat secara mekanis. Pada pengamatan di lapangan banyak diminati petani dan tanaman tersebut sering ditanam secara berdampingan pada areal yang sama dengan tanaman pepaya. Pola tanam seperti ini seharusnya dihindari karena selain dapat melestarikan keberadaan virus mosaik juga memungkinkan terjadinya infeksi campuran atau terjadinya mutasi menjadi strain yang lebih virulen.

Hal ini merupakan informasi yang penting dalam usaha pengendalian penyakit tersebut berdasarkan pola penanaman pepaya oleh petani di lapang. Hal tersebut di atas perlu diwaspadai karena selain sebagai inang alternatif dan sumber inokulum, tanaman mentimun dan amaranthaceae juga berperan dalam melestarikan virus mosaik tersebut yang diduga merupakan kelompok Potyvirus sepanjang tahun. Taksonomi Potyvirus, sebagai kelompok virus tumbuhan terbesar yang menyerang tanaman, sampai saat ini masih menjadi perdebatan karena besarnya variasi antara spesies. Runutan asam amino protein selubung (coat protein/CP) telah dicoba digunakan untuk menilai kekerabatan 17 isolat dari delapan spesies Potyvirus. Hasil kajian menunjukkan antara spesies Potyvirus yang berbeda terdapat tingkat kesamaan runutan asam amino dari CP sebesar $38-71 \%$ dan antara galur yang berbeda dalam spesies virus yang sama mempunyai tingkat kesamaan mencapai 99\%. Genus Potyvirus memiliki inang yang cukup banyak dan bervariasi dari beberapa famili tanaman diantaranya yaitu
Amaranthaceae, Chenopodiaceae, Compositae, Labiateae, dan Solanaceae (Hadiastono, 2010).

\section{KESIMPULAN}

Gejala infeksi virus pada tanaman pepaya yang diperoleh dari 3 lokasi berbeda yakni Kabupaten Toraja, Kabupaten Gowa dan Kabupaten Mamasa bervariasi. Pengujian respon tanaman indikator terhadap 25 isolat virus mosaik secara mekanik memperlihatkan 19 isolat virus yang dapat menginfeksi kelima tanaman indikator dengan persentase penularan dan lama periode inkubasi virus berbeda-beda, sedangkan 6 isolat lainnya tidak dapat menginfeksi tanaman indikator.

\section{DAFTAR PUSTAKA}

Brunt, A. K., Crabtree and A. Gibbs, (2011). Viruses of Tropical. CAB Internasional. pp. 707.

Davis RI, Mu L, Maireroa N, Wigmore WJ, Grisoni M, Bateson MF, Thomas JE. (2005). First records of the papaya strain of Papaya ringspot virus (PRSV$P)$ in French Polynesia and the Cook Island. Austr Plant Pathol. 34(1):125126. doi:10.1071/AP04094.

Davis, R. F., and Mazumi, M. K. (2007). Detection of Cucurbit Viruses in New Jarsey. Plant Dis. 71:40-44.

Garrett, A., (2011). The pollination biology of papaw (Carica papaya L.) in Central Queensland. PhD. Thesis, Central Queensland University, Rockhampton, $125 \mathrm{pp}$

Gonsalves D, Tripathi S, Carr J.B, Suzuki J.Y. (2010). Papaya ringspot virus [Internet]. St. Paul (US): The American Phytophatological Society; [diunduh 2013 Mar 23]. Tersedia pada: http:// www.apsnet.org.

Hadiastono, T., (2010). Virologi Tumbuhan Dasar. Fakultas Pertanian. Universitas 
Brawijaya. Malang.

Hidayat, S. H., Nurulita, S. dan Wiyono, S., (2012). Infeksi Papaya ringspot virus pada Tanaman Pepaya di Provinsi Nanggroe Aceh Darussalam. J. Fitopatologi Indonesia Vol. 8 (2) : 184187.

Jamsari., (2007). Bioteknologi Pemula: Prinsip Dasar dan Aplikasi Analisis Molekuler. Unri Press. Riau

Jensen, D.D., (2010). Papaya virus diseases with special reference to papaya ringspot. Phytopathol 39 : 191-211.

Mazumi, H., A. Samei, A. H. Pour, M. Shaabanian and H. Rahimian. (2007). Occurrence, distrivution and relative incidence of sevent virus infecting greenhouse-grown cucurbits in Iran. Plant Dis. 91:159-163.

Noveriza R, Suastika G, Hidayat S.R, Kartosuwondo U. 2012. Pengaruh Infeksi Virus Mosaik terhadap Produksi dan kadar Minyak Tiga Varietas Nilam. Bul.Littro.Vol.23 No.1. 93-101.

Nameth, ST. (2002). Mosaic Virus Diseases of Vine Crops. Extension FactSheet.

Singh, M.K., V. Chandel., V. Hallan., R. Ram \& A.A. Zaid. (2009). Occurrence of Peanut stripe virus on patchouli and raising of virus-free patchouli plants by meristem tip culture. Journal of Plant Diseases and Protection 116 : 2-6.

Soedarya, A.P. (2009). Agribisnis Pepaya. Pustaka Grafika. Bandung. 